\title{
TRADISI PERNIKAHAN PADA BULAN SYAWAL DI MADURA: KAJIAN LIVING HADITH
}

\author{
Mohammad Subhan Zamzami \\ Institut Agama Islam Negeri (IAIN) Madura, Jawa Timur \\ mszamzami@stainpamekasan.ac.id \\ Artikel diterima 26 Februari, diseleksi 23 Mei, dan disetujui 25 Juni 2018
}

\begin{abstract}
This paper discloses the tradition of marriage in the month of Shawal in the sub-district of Pamekasan, Madura, from 2013 to 2017, in terms of its rituals and technicalities. This paper is a result of a fieldwork research employing the approach of Living Hadis. This research has discovered the tradition of Shawal marriage as a form of marriage traditions in Madura that has been present from generation to generation, and strongly rooted within the society. It has diverse rituals, technicalities, and various views on its existence, which has wittingly or unwittingly become as one of socio-religious practices that has been actually influenced by traditions of Islamic marriage strongly rooted from Hadis of the Prophet.
\end{abstract}

Keywords: Living Hadis, Phenomenon, Marriage, Shawal, Madura.

\section{PENDAHULUAN}

Islam mengatur semua sendi kehidupan dengan memberikan prinsip-prinsip dasarnya, sedangkan detailnya diserahkan kepada kreatifitas pemeluknya selama sesuai dengan prinsip-prinsip dasar tersebut. Salah satu sendi kehidupan yang diatur Islam berdasarkan ketentuan tersebut adalah pernikahan. Pernikahan merupakan tradisi sosial kuno yang tetap bertahan hingga sekarang dengan beragam cara, bentuk, dan waktunya. Berdasarkan cara dan bentuknya, misalnya, orang

\begin{abstract}
Abstrak
Artikel ini berusaha mengungkap tradisi pernikahan pada bulan Syawal di Kecamatan Pamekasan Kabupaten Pamekasan Madura sejak tahun 2013 hingga tahun 2017 dari segi tata caranya. Artikel ini merupakan hasil penelitian lapangan yang menggunakan pendekatan living hadith. Penelitian ini berhasil mengungkap tradisi pernikahan pada bulan Syawal termasuk salah satu bentuk tradisi pernikahan Madura yang sudah berlangsung secara turun-menurun dan mengakar kuat di tengah masyarakat yang cara penentuan dan pandangan tentang eksistensinya beragam, sehingga tidak disadari sebagai salah satu praktik sosial-keagamaan yang sebenarnya dipengaruhi oleh tradisi pernikahan Islam yang eksistensinya berasal dari hadis Nabi.
\end{abstract}

Kata kunci: Living Hadith, Fenomena, Pernikahan, Syawal, Madura.

Arab pra-Islam mengenal empat macam pernikahan sebagaimana kisah 'Â'isyah, istri Nabi, dalam hadis sahih dalam Shahîh $\underline{h}$ al-Bukhârî berikut (al-Bukhârî, 2002: 1307):

"Sesungguhnya pernikahan pada zaman Jahiliah ada empat macam. Di antaranya pernikahan orang seperti sekarang ini. Seorang pria melamar kepada pria lain anak perempuan yang berada di bawah kewaliannya dan anak perempuannya, lalu dia memberikan mahar kemudian menikahi perempuan tersebut. Pernikahan lain adalah seorang 
pria mengatakan kepada istrinya, ketika dia telah suci dari haidnya, "Datanglah kamu kepada Fulan. Mintalah keturunan darinya!" Suaminya lalu menjauhi (tidak meniduri) dia, tidak menyentuh dia hingga saat tampak telah hamil dari pria yang dimintai keturunannya itu. Ketika kehamilannya tampak jelas, perempuan tersebut akan dinilai melakukan hal yang benar oleh suaminya jika suaminya menginginkan hal demikian. Dia melakukan itu karena ingin mendapatkan bibit unggul. Pernikahan seperti ini disebut nikah istibdlâ'. Pernikahan lain adalah, sekelompok pria berkumpul, jumlahya kurang dari sepuluh. Mereka menyetubuhi seorang perempuan. Semuanya mendapatkan bagian dari perempuan tersebut. Jika dia hamil, dan melahirkan, kemudian berlalu beberapa malam setelah melahirkan, maka dia mengirimkan surat kepada pria-pria tersebut. Tidak seorang pun di antara mereka bisa mengelak hingga semuanya berkumpul di dekat perempuan tersebut. Dia lalu berkata kepada mereka, "Kalian sudah tahu hasil perbuatan kalian. Sekarang saya sudah melahirkan." Lalu dia akan menunjuk pria yang diinginkan dengan mengatakan, "Ini anakmu, wahai Fulan." Anak ini pun dinisbatkan kepadanya. Tidak seorang pun di antara mereka bisa mengelak. Pernikahan keempat, ketika banyak orang berkumpul, lalu mereka meniduri seorang perempuan, dan perempuan ini tidak bisa menolak siapa pun yang datang kepadanya. Perempuanperempuan ini adalah pelacur. Mereka telah memasang bendera di pintu mereka sebagai pertanda.
Siapa saja yang menginginkan wanita itu, dia bisa masuk dan meniduri dirinya. Jika salah seorang di antaranya hamil, lalu melahirkan anaknya, para pria itu dikumpulkan, mereka pun diundi. Anak perempuan tadi kemudian dinisbatkan kepada pria yang mereka sepakati. Ketika Muhammad saw. diutus dengan membawa kebenaran, semua pernikahan Jahiliah itu dihancurkan, kecuali pernikahan yang ada saat ini.'"'

Selain empat macam pernikahan tersebut, Jawwâd 'Alî juga mencatat beberapa macam pernikahan orang Arab pra-Islam, seperti nikah muqt atau dlizzan, nikah mut'ah, nikah badal, nikah syighâr, nikah khidn, nikah dza'înah, dan nikah poligami tanpa batasan istri ('Alî, 1993: 5/534-548). Sedangkan berdasarkan waktunya, orang Arab praIslam juga mengenal waktu tertentu untuk pernikahan. Salah satunya adalah pernikahan di bulan Syawal. Mereka tidak suka menikah pada bulan Syawal, karena mereka menganggap bulan Syawal sebagai bulan sial (al-Nawawî, 1929: 9/209).

Dalam tradisi Jahiliah, penamaan bulan Syawal memang identik dengan pernikahan. Dinamakan Syawal, karena pada bulan ini unta menaikkan ekornya sebagai isyarat tidak mau kawin, yang kemudian orang Arab menjadikan bulan ini sebagai bulan pantangan untuk menikah karena menganggapnya sebagai bulan sial (Ibn Mandzûr, t.th.: 4/2365). Pada saat Islam datang, Islam menghapus tradisi pernikahan Jahiliah ini dengan contoh langsung dari Nabi Muhammad Saw. berupa pernikahan beliau dengan 'Â'isyah. Muslim (206-261 H.) mencatat kisah pernikahan tersebut dalam Shahîh Muslim sebagai berikut (Muslim, 1998: 739):

Jurnal Multikultural \& Multireligius Vol. 17 $\mid$ No. 


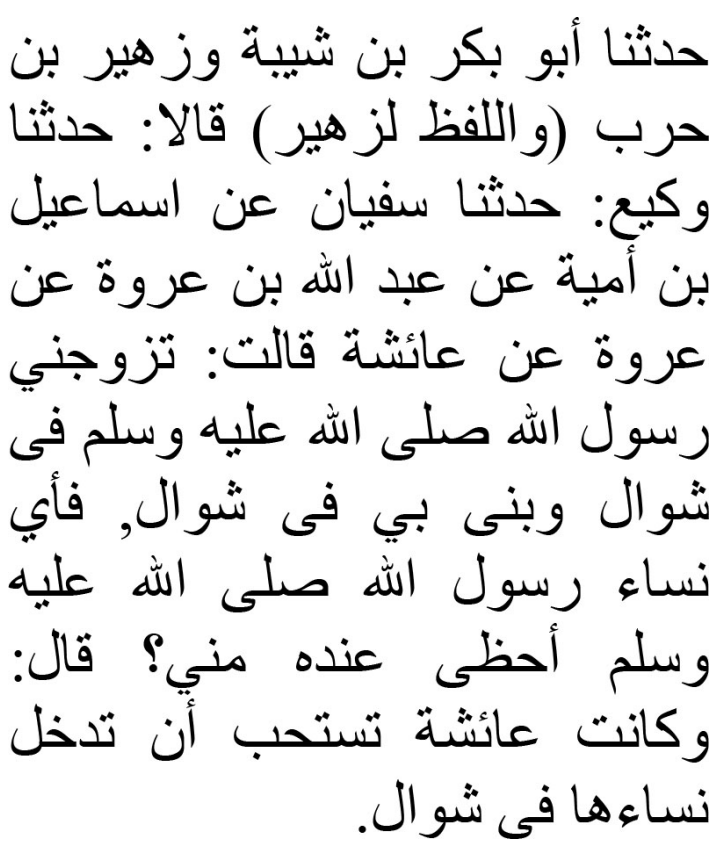

"Abû Bakr ibn Syîbah dan Zuhair

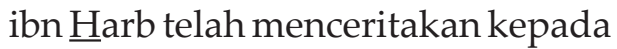
kami (dan redaksi hadis ini milik Zuhair). Keduanya berkata: "Wakî' telah menceritakan kepada kami: Sufyân telah menceritakan kepada kami, dari Ismâ‘̂̂l ibn Umayah, dari ‘Abd Allâh ibn ‘Urwah, dari ‘Urwah, dari 'Â'isyah, beliau berkata, "Rasulullah saw. menikahiku pada bulan Syawal dan berumahtangga denganku pada bulan Syawal. Siapakah istri Rasulullah saw. yang lebih memiliki kedekatan hati di sisi beliau daripada aku?" Dia berkata, "'Â'isyah senang mempertemukan para mempelai wanita (ke tempat para mempelai pria) pada bulan Syawal."

Pernikahan Nabi dengan 'Â'isyah pada bulan Syawal selain bermuatan nilai-nilai agama sebagai penerus sunah para nabi (al-Tirmidzî, t.th.: 255), juga bermuatan nilai-nilai sosial. Nilai-nilai inilah yang terus bertahan di tengah umat Islam, terutama di Madura, hingga saat ini. Di Madura, pernikahan diselenggarakan secara variatif, baik dari segi cara, bentuk, maupun waktunya. Dari segi bentuk, orang Madura mengenal pangantan tandhu (Nurdiana, 2012: 1-26), robbhu bhâta, dan salèp tarjhâ (Rochmah, 2011: 54). Sedangkan dari segi waktunya, mereka biasa menggelar pernikahan pada bulan-bulan tertentu, seperti bulan Zulhijah, Jumadilawal, Syakban, dan Syawal berdasarkan tradisi yang sudah berkembang secara turun-temurun dalam menentukan hari dan tanggal pernikahan, yang mereka sebut dengan istilah nyarè dhina.

Khusus tradisi pernikahan pada bulan Syawal di Madura, terutama di Kecamatan Pamekasan Kabupaten Pamekasan, warga setempat juga biasa menggelar pernikahan pada bulan ini. Hal ini berdasarkan data pernikahan dari Kementerian Agama Kabupaten Pamekasan untuk Kecamatan Pamekasan dari tahun 2013 sampai 2016 berikut ini (Kementerian Agama Kabupaten Pamekasan, 2013-2016):

\begin{tabular}{|c|c|c|c|c|}
\hline \multirow{2}{*}{ Bulan } & \multicolumn{4}{|c|}{ Tahun } \\
\cline { 2 - 5 } & $\mathbf{2 0 1 3}$ & $\mathbf{2 0 1 4}$ & $\mathbf{2 0 1 5}$ & $\mathbf{2 0 1 6}$ \\
\hline Januari & 21 & 13 & 60 & 85 \\
\hline Februari & 69 & 125 & 77 & 54 \\
\hline Maret & 54 & 42 & 47 & 38 \\
\hline April & 42 & 52 & 39 & 43 \\
\hline Mei & 53 & 50 & 58 & 79 \\
\hline Juni & 81 & 86 & 45 & 13 \\
\hline Juli & 16 & 10 & 59 & 91 \\
\hline Agustus & 88 & 100 & 66 & 35 \\
\hline September & 37 & 28 & 111 & 149 \\
\hline Oktober & 143 & 137 & 79 & 29 \\
\hline November & 38 & 31 & 20 & 38 \\
\hline Desember & 60 & 60 & 23 & 29 \\
\hline Jumlah & 702 & 734 & 684 & 683 \\
\hline
\end{tabular}

Berdasarkan data tersebut, tradisi pernikahan pada bulan Syawal di Kecamatan Pamekasan Kabupaten Pamekasan Madura yang sama dengan waktu pernikahan Nabi dengan 'Â'isyah tersebut dan 'Â'isyah senang mempertemukan mempelai wanita (ke tempat mempelai pria) pada bulan Syawal sebagaimana teks hadis di atas tentu perlu 
diteliti lebih jauh. Apalagi penelitian tentang tradisi pernikahan di Madura selama ini belum menyentuh persoalan ini secara spesifik, sehingga penelitian ini bisa memanfaatkan penelitian sebelumnya untuk mengembangkannya dengan temuan baru.

Untuk meneliti fenomena tersebut, penelitian ini berusaha menjawab empat persoalan, yaitu pernikahan dalam Islam, tradisi pernikahan di Madura, tradisi pernikahan di Madura dalam perspektif Islam, dan tradisi pernikahan di bulan Syawal di Kecamatan Pamekasan Kabupaten Pamekasan Madura dalam perspektif living hadith.

\section{METODE}

Penelitian ini didasarkan pada data Rekap Nikah Rujuk (Model F1) Tahun 2013, 2014, 2015, dan 2016 Kabupaten Pamekasan, observasi, wawancara dengan sejumlah informan, arsip, dan buku. Untuk mengolah data tersebut, penelitian ini menggunakan pendekatan living hadith.

Living hadith adalah gejala yang muncul di tengah masyarakat berupa pola-pola perilaku yang berasal dari hadis Nabi Muhammad saw. (Suryadilaga, 2013: 164) atau studi ilmiah tentang peristiwa sosial yang terkait dengan eksistensi hadis di suatu komunitas Muslim (Aini, 2014: 227). Living hadith fokus pada studi tentang fenomena praktik, tradisi, ritual, dan perilaku yang hidup di tengah masyarakat yang memiliki dasar atau eksistensinya diilhami dari hadis (Qudsy, 2016: 182). Pendekatan living hadith digunakan karena objek penelitian ini terkait dengan hadis-hadis pernikahan pada bulan Syawal dan fenomena tersebut merupakan tradisi masyarakat setempat.

\section{HASIL DAN PEMBAHASAN}

\section{Pernikahan Sebagai Tradisi Sosial- Keagamaan}

Dalam Lisân al-'Arab, Ibn Mandzûr (1233-1312 M.) menyebutkan tiga makna "nikâh" yaitu "wath"', "'aqd", dan "budl"'. Kata "wath"' merupakan kata asal untuk pernikahan di kalangan orang Arab. Pernikahan disebut wath', karena ia merupakan sebab yang membolehkan untuk melakukan hubungan suami-istri. Sebenarnya, kata "nikâh" merupakan kata ambigu, sehingga pemaknaan kata ini tergantung pada penggunaannya dalam sebuah kalimat sempurna, seperti (1) Nakaha Fulân imra'ah yang berari Fulan "menikahi seorang perempuan", (2) Nakaha al-mathar al-ardl yang berarti "tempat yang dibasahi hujan", dan (3) Nakaha al-nu'âs al-'ayn yang berarti "kantuk mengalahkan matanya" (Ibn Mandzûr: 6/4537-4538).

Sayangnya, Ibn Mandzûr hanya mendefinisikan pernikahan dari aspek etimologisnya, sehingga kita perlu melihat definisi pernikahan dari pakar yang lain, seperti 'Alî ibn Muhammad alSayyid al-Syarîf al-Jurjânî (740-816 H.). Dalam kitab al-Ta'rîfât, ia mendefinisikan nikah dari aspek etimologis dan terminologisnya. Dari aspek etimologis,

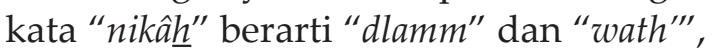
sedangkan dari aspek terminologis kata "nikâhn" berarti "'aqd yaridu 'ala tamlîk manfa'ah al-budl' qashdan" [akad untuk memperoleh manfaat pernikahan dengan cara disengaja] (al-Jurjânî, t.th.: 206). Dengan demikian, pernikahan adalah sebuah akad yang melibatkan dua orang atau lebih dengan cara yang disengaja untuk memperoleh manfaat pernikahan.

Dalam Islam, pernikahan termasuk perkara penting, sehingga ia termasuk dalam satu kategori dalam al-dlarûrîyât alkhamsah, yaitu untuk menjaga keturunan 
(hiffdz al-nasl), yang menurut al-Syâthibî harus dilakukan agar mendapatkan kemaslahatan hidup di dunia dan akhirat (al-Syâthibî, t.th.: 7-8). Kemasalahatan ini bisa dicapai dengan pernikahan, sehingga Allah Swt. menjadikannya sebagai bagian dari syariat-Nya, baik melalui Alquran maupun melalui Nabi Muhammad saw.

Dalam Alquran, kita bisa menemukannya dalam banyak ayat seperti dalam surah al-Baqarah [2]: 221, 230, 232, 235, 237, surah al-Nisâ' [4]: 3, 6, 22, 25, 128, 221, surah al-Nûr [24]: 3, 32, 33, 60, surah al-Qashash [28]: 27, surah al-Ahzâb [33]: 49, 50, 53, dan surah alMumtahanah [60]: 10 ('Abd al-Bâqî, $1364 \mathrm{H}$ : 718). Sebagai penerima wahyu dan penafsir utama Alquran, Nabi menganjurkan umatnya menikah dan melarang hidup membujang, sehingga persoalan kehidupan mereka di dunia dan akhirat bisa seimbang, sebagaimana akan diungkap pada pembahasan berikutnya.

Di kalangan masyarakat Madura, ada lima istilah yang biasa digunakan untuk pernikahan; dua kata berbentuk verba yaitu "alakè" dan "abine" dan tiga kata lainnya berbentuk nomina yaitu "neka", "kabin", dan "mantan". Kata "alake" bermakna "perempuan menikah dengan laki-laki" yang biasanya ditujukan untuk perempuan, sedangkan kata "abine" bermakna "laki-laki menikah dengan perempuan" yang biasanya ditujukan untuk laki-laki. Di sisi lain, kata "neka" dan "kabin" lebih menunjukkan pada wujud pernikahan itu sendiri, sedangkan kata "mantan" lebih menunjukkan pada sepasang pengantin.

Siti Rochmah membagi proses pernikahan dalam adat Madura menjadi tiga tahap: Pertama, adat sebelum perkawinan, yang meliputi (1) Pemilihan jodoh; (2) Prosesi pertunangan ngangène, (3) Prosesi pertunangan nerabhâs paghâr; (4) Prosesi pertunangan nalèè paghâr; (5)

\begin{tabular}{l|l} 
HARMONI & Januari - Juni 2018
\end{tabular}
Prosesi pertunangan lamaran; dan (6) Nyeddhâk temmo. Kedua, upacara-upacara pelaksanaan perkawinan, yang meliputi akad dan resepsi pernikahan yang bisa berlangsung satu hingga tiga harimalam. Ketiga, upacara-upacara sesudah perkawinan, yang meliputi pèlèt kandung dan upacara kelahiran (Rochmah: 4553). Tahap pernikahan ini tidak berlaku secara kaku, karena meski sama secara substansi tapi setiap daerah memiliki tradisi pernikahan yang berbeda pada detail prosesinya.

\section{Hadis Pernikahan Pada Bulan Syawal}

Dalam literatur hadis kanon seperti al-kutub al-sittah, hadis-hadis tentang pernikahan termaktub di dalamnya, bahkan dalam sebuah bab khusus tentang pernikahan. Dalam Shahîh $\underline{h}$ al-Bukhârî, hadis tentang pernikahan termaktub sebanyak 187 hadis, yaitu dari hadis nomor 5063 hingga hadis nomor 5250 (al-Bukhârî: 1292-1337). Dalam Shahîh $\underline{\text { }}$ Muslim, hadis tentang pernikahan termaktub sebanyak 43 hadis, yaitu dari hadis nomor 1400 hingga hadis nomor 1443 (Muslim: 724-758). Dalam Sunan Ab̂ิ Dâwud, hadis tentang pernikahan termaktub sebanyak 28 hadis, yaitu dari hadis nomor 2046 hingga hadis nomor 2174 (Abû Dâwud, t.th.: 355-378). Dalam Sunan al-Tirmidzî, hadis tentang pernikahan termaktub sebanyak 65 hadis, yaitu dari hadis nomor 1080 hingga hadis nomor 1145 (al-Tirmidzî: 255-272). Dalam Sunan al-Nasâ' $\hat{\imath}$, hadis tentang pernikahan termaktub sebanyak 192 hadis, yaitu dari hadis nomor 3196 hingga hadis nomor 3388 (al-Nasâ'î, t.th.: 495-524). Terakhir, dalam Sunan Ibn Mâjah, hadis tentang pernikahan termaktub sebanyak 170 hadis, yaitu dari hadis nomor 1845 hingga hadis nomor 2015 (Ibn Mâjah, t.th.: 321348).

Berdasarkan al-kutub al-sittah 
tersebut, secara kuantitas, hadis tentang pernikahan sebanyak 685 hadis. Kuantitas hadisiniakanbertambahbilahadistentang pernikahan dalam buku induk hadis lain, seperti Muwattha' Mâlik, Sunan al-Dârimî, dan Musnad Ahmad juga disertakan. Oleh karena itu, penelitian ini hanya akan meneliti hadis-hadis tentang pernikahan di bulan Syawal yang diriwayatkan oleh Muslim dalam Shaĥîh Muslim, al-Tirmidzî dalam Sunan al-Tirmidzî, al-Nasâ'î dalam Sunan al-Nasâ'î, Ibn Mâjah dalam Sunan Ibn Mâjah, al-Dârimî dalam Musnad alDârimî atau Sunan al-Dârimî, dan Ahmad dalam al-Musnad sebagaimana diungkap sebelumnya dan akan diuraikan pada pembahasan berikut.

Dalam Shahîh $\underline{h}$ Muslim, Muslim meriwayatkan sebuah hadis sahih dalam Bâb Istihhbâb al-Tazawwwuj wa al-Tazwîj fi Syawwâl wa Istihhbab al-Dukhûl fîhi sebagai berikut (Muslim: 739):

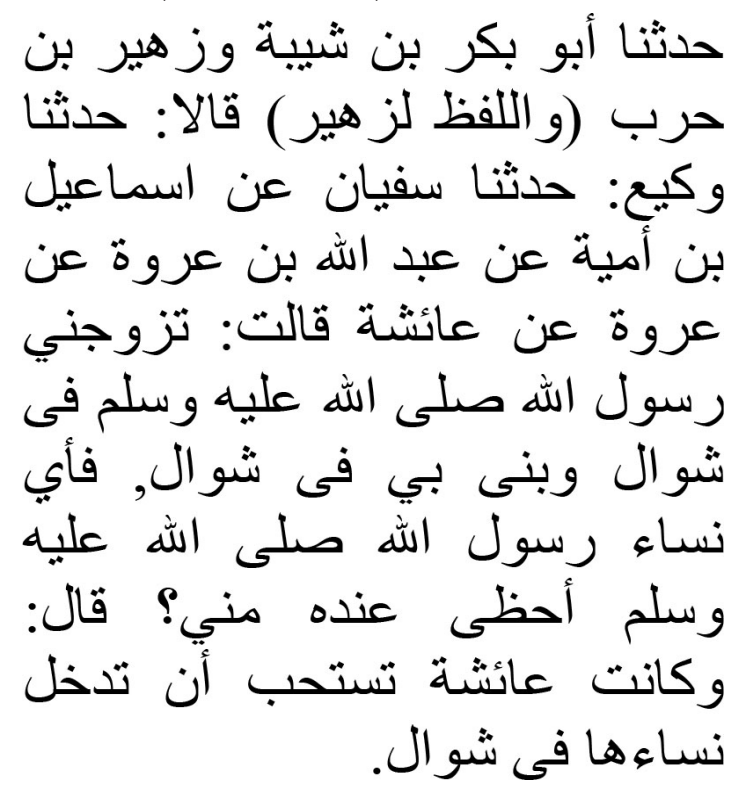

"Abû Bakr ibn Syîbah dan Zuhair

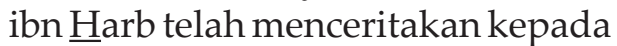
kami (dan redaksi hadis ini milik Zuhair). Keduanya berkata: "Wakî' telah menceritakan kepada kami: Sufyân telah menceritakan kepada kami, dari Ismâ'îl ibn Umayah, dari 'Abd Allâh ibn 'Urwah, dari ‘Urwah, dari 'Â'isyah, beliau berkata, "Rasulullah saw. menikahiku pada bulan Syawal dan berumahtangga denganku pada bulan Syawal. Siapakah istri Rasulullah saw. yang lebih memiliki kedekatan hati di sisi beliau daripada aku?" Dia berkata, "'Â'isyah senang mempertemukan para mempelai wanita (ke tempat para mempelai pria) pada bulan Syawal."

Dalam Sunan al-Tirmidzî, alTirmidzî meriwayatkan hadis hasan shahîh $\underline{h}$ gharîb dalam Bâb Mâ Jấa fì al-Auqât allatî Yustahabbu fihâ al-Nikâh sebagai berikut (al-Tirmidzî: 258):

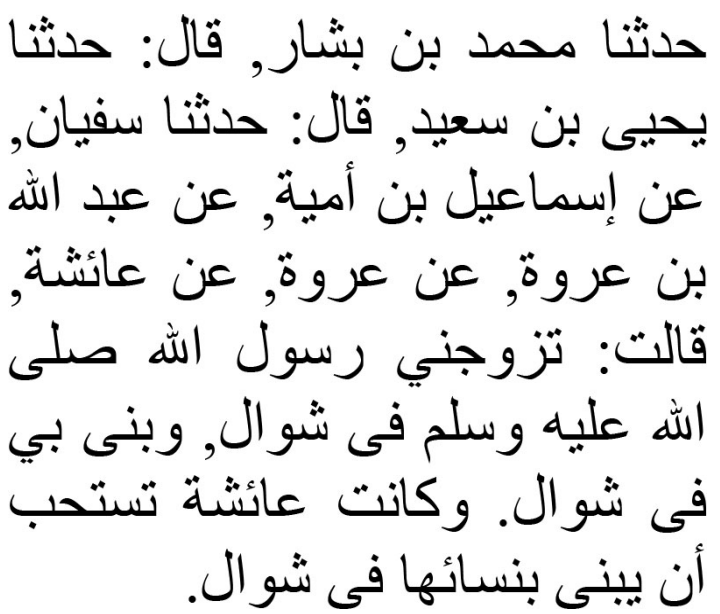

"Muhammad ibn Basysyâr telah menceritakan kepada kami, dia berkata: "Yahyâ ibn Sa'îd telah menceritakan kepada kami, dia berkata: "Sufyân telah menceritakan kepada kami dari Ismâ'îl ibn Umayah dari 'Abd Allâh ibn 'Urwah dari 'Urwah dari 'Â'îsyah, beliau berkata, "Rasulullah saw. menikahiku pada bulan Syawal dan berumahtangga denganku pada bulan Syawal. 'Â'isyah senang mempertemukan para mempelai wanita (ke tempat para mempelai pria) pada bulan Syawal."

Dalam Sunan al-Nasâ'î, al-Nasâ'î meriwayatkan sebuah hadis sahih dalam Bâb al-Tazwî̀ fî Syawwâl sebagai berikut (al-Nasâ'î: 501):

\begin{tabular}{l|l} 
Jurnal Multikultural \& Multireligius Vol. 17 & No. 1
\end{tabular} 
أخبرنا عبيد الله بن سعبد قال: حدثنا يحيى عن سفيان قال: حدثني عن اسماعيل بن أمية عن عبد الله بن عروة عن عروة عن عائشة, قالت: تزوجني رسول الله صلى الله عليه وسلم فى شو ال, وأدخلت عليه فى شو ال, وكانت عائشة تحب أن تدخل نساءها فى شوال, فأي نساءه كانت أحظى عنده مني؟

“'Ubaid Allâh ibn Sa'îd telah menceritakan kepada kami, dia berkata: "Yahyâ telah menceritakan kepada kami dari Sufyân, dia berkata: "Ismâ'îl ibn Umayah telah menceritakan kepadaku dari 'Abd Allâh ibn 'Urwah, dari 'Urwah, dari 'Â'isyah, beliau berkata, "Rasulullah saw. menikahiku pada bulan Syawal dan aku berumahtangga dengannya pada bulan Syawal." 'Â'isyah senang mempertemukan para mempelai wanita (ke tempat para mempelai pria) pada bulan Syawal. Siapakah istri beliau yang lebih memiliki kedekatan hati di sisi beliau daripada aku?"

Dalam Sunan Ibn Mâjah, Ibn Mâjah meriwayatkan dua hadis yang terdiri dari satu hadis sahih dan satu hadis mursal dalam Bâb Matâ Yustahabbu al-Binấ bi alNisâ' sebagai berikut (Ibn Mâjah:344-345):

حدثنا أبو بكر بن شيبة, قال: حدثنا

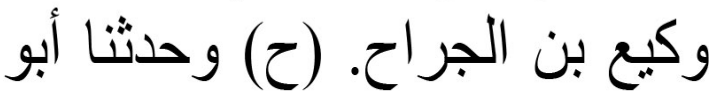
بشر بكر بن خلف, قال: حدثنا

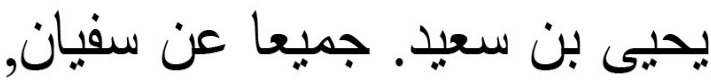
عن اسماعيل بن أمية, عن عبد الله
بن عروة, عن عروة, عن عائشة, قالت: تزوجني النبي صلى الله عليه وسلم فى شو ال, وبنى بي فى في شو ال, فأي نساءه كان أحظى عنده مني! وكانت عائشة تستحب أن تذخل نساءها فى شو ال.

"Abû Bakr ibn Syîbah telah menceritakan kepada kami, dia berkata: "Wakî̀ ibn al-Jarrâh telah menceritakan kepada kami, dan Abû Bisyr Bakr ibn Khalaf telah menceritakan kepada kami, dia berkata: "Yahyâa ibn Sa'îd telah menceritakan kepada kami. Semuanya dari Sufyân, dari Ismâ'îl ibn Umayah, dari 'Abd Allâh ibn 'Urwah, dari 'Urwah, dari 'Â'isyah, beliau berkata, "Nabi saw. menikahiku pada bulan Syawal dan berumahtangga denganku pada bulan Syawal. Siapakah istri beliau yang lebih memiliki kedekatan hati di sisi beliau daripada aku?" "'Â'isyah senang mempertemukan para mempelai wanita (ke tempat para mempelai pria) pada bulan Syawal."

حدثنا أبو بكر بن شيبة, قال: حدثنا أسود بن عامر, قال: حدثنا ز هير, عن محمد بن إسحاق, عن عبد الله بن أبي بكر, عن أبيه, عن عن عن عن عن الملك بن الحارث بن بن هثاح, عن إن أبيه: أن النبي صلى الله عليه وسلم تزوج أم سلمة في شوال الني وجمعها إليه في شو ال. 
"Abû Bakr ibn Syîbah telah menceritakan kepada kami, dia berkata: "Aswad ibn 'Âmir telah menceritakan kepada kami, dia berkata: "Zuhair telah menceritakan kepada kami dari Muhammad ibn Ishâqq dari 'Abd Allâh ibn Abû Bakr dari bapaknya dari 'Abd al-

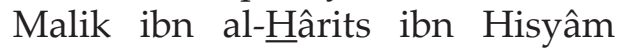
dari bapaknya bahwa Nabi saw. menikahi Ummu Salamah pada bulan Syawal dan berumahtangga dengannya pada bulan Syawal."

Dalam Musnad al-Dârimî atau Sunan al-Dârimî, al-Dârimî meriwayatkan sebuah hadis sahih dalam Bâb Binấ alRajul bi Ahlihi fî Syawwâl sebagai berikut (al-Dârimî, 2000: 1418-1419):

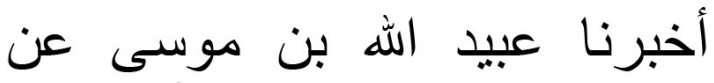

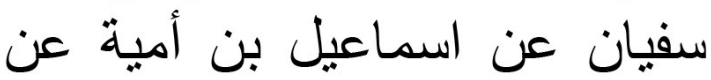

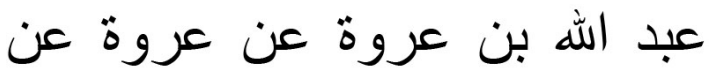
عائشة, قالت: تزوجن بعني رسول الله

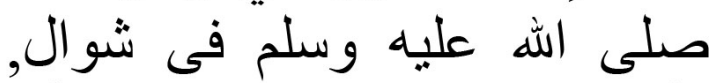
و أدخلت عليه فى شوال, فأي نساءه كان أحظى عنده مني؟ قالت: وكانت تستحب أن تشخل على النساء فى شو ال.

“'Ubaid Allâh ibn Mûsâ telah menceritakan kepada kami dari Sufyân dari Ismâ'îl ibn Umayah dari 'Abd Allâh ibn ‘Urwah, dari ‘Urwah, dari 'Â'isyah, beliau berkata, "Rasulullah saw. menikahiku pada bulan Syawal dan aku berumahtangga dengannya pada bulan Syawal. Siapakah istri beliau yang lebih memiliki kedekatan hati di sisi beliau daripada aku?" Beliau berkata: "Dia senang mempertemukan para mempelai wanita (ke tempat para mempelai pria) pada bulan Syawal."
Dalam al-Musnad, Ahmad meriwayatkan dua hadis sahih sebagai berikut (Ahmad, 1995: 17/279 dan 18/3637):

حدثنا بحيى بن سعيد عن سفيان, عن اسماعيل بن أمبة, قال: حدثني

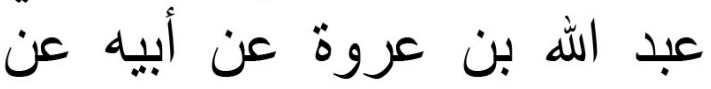
عائشة قالت: تزوجني رسول الله

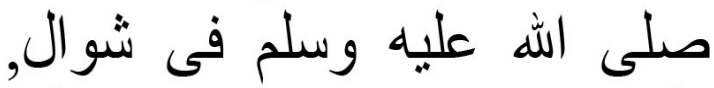

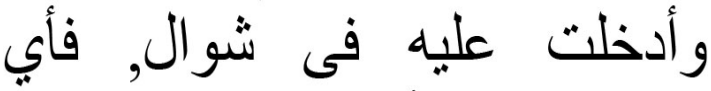
نساءه كان أحظى عنده مني, فكانت تستحب أن تذخل نساءها

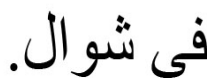

"Yahyâ ibn Sa'îd telah menceritakan kepada kami dari Sufyân, dari Ismâ‘̂̂l ibn Umayah, dia berkata: “'Abd Allâh ibn 'Urwah telah menceritakan kepadaku dari bapaknya dari 'Â'isyah, beliau berkata, "Rasulullah saw. menikahiku pada bulan Syawal dan aku berumahtangga dengannya pada bulan Syawal. Siapakah istri Rasulullah saw. yang lebih memiliki kedekatan hati di sisi beliau daripada aku?" “'Â'isyah senang mempertemukan para mempelai wanita (ke tempat para mempelai pria) pada bulan Syawal."

حدثنا وكيع ثنا سفيان عن اسماعيل

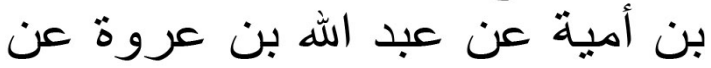

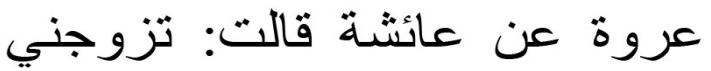

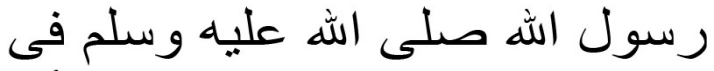
شوال, وبنى بي فى شو اله اله, فأي

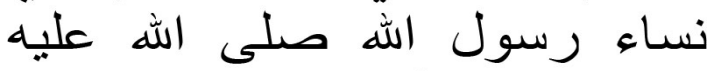

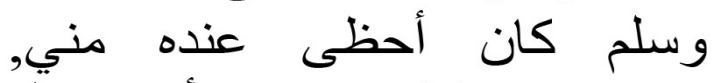
وكانت عائشة تستحب أن أن تدخلّ نساء ها في شو الل.

\begin{tabular}{l|l} 
Jurnal Multikultural \& Multireligius Vol. 17 & No. 1
\end{tabular} 
"Wakî̀ telah menceritakan kepada kami, Sufyân telah menceritakan kepada kami dari Ismâ'îl ibn Umayah, dari 'Abd Allâh ibn 'Urwah, dari 'Urwah, dari 'Â'isyah, beliau berkata, "Rasulullah saw. menikahiku pada bulan Syawal dan berumahtangga denganku pada bulan Syawal. Siapakah istri Rasulullah saw. yang lebih memiliki kedekatan hati di sisi beliau daripada aku?" "'Â'isyah senang mempertemukan para mempelai wanita (ke tempat para mempelai pria) pada bulan Syawal."

Jika diperhatikan, semua hadis di atas bersumber dari Sufyân Ismâ'îl ibn Umayah 'Abd Allâh ibn 'Urwah, dan 'Urwah yang berakhir pada 'Â'isyah yang semuanya menceritakan tentang pernikahan Nabi Muhammad saw. dengan 'Â'isyah pada bulan Syawal, kecuali sebuah hadis mursal dalam Sunan Ibn Mâjah yang memiliki struktur sanad dan matan yang berbeda, yaitu pernikahan Nabi Muhammad saw. dengan Ummu Salamah pada bulan Syawal. Jadi, secara substansi, hadishadis tersebut menjelaskan tentang praktik pernikahan Nabi Muhammad saw. dengan 'Â'isyah dan Ummu Salamah pada bulan Syawal, yang dalam 'ulûm al-hadîts disebut sebagai hadîts fi'tî atau sunnah fíliyah.

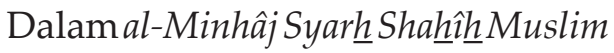

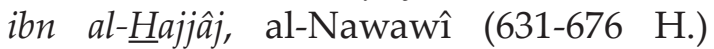
menjelaskan hadis koleksi Shaĥîh Muslim di atas bahwa hadis ini mengandung anjuran menikah dan berumahtangga pada bulan Syawal, sehingga ulama mazhab Syâfi'î menjadikannya sebagai dalilnya. Dengan hadis ini, 'Â'isyah, menurutnya, hendak menganulir tradisi Jahiliah dan anggapan orang awam pada masa al-Nawawî bahwa pernikahan pada bulan Syawal tidak baik (alNawawî: 209). Dengan demikian, hadis ini merupakan contoh konkret tindakan
Nabi Muhammad saw. dalam menghapus tradisi Jahiliah yang tidak baik. Pendapat al-Nawawî didukung oleh al-Mubârakfûrî (1283-1353 H.) dalam Tuhfah al-Ahwoadzî bi Syarh Jâmi' al-Tirmidzî saat menjelaskan hadis koleksi Sunan al-Tirmidzî di atas. Dia juga mengutip pendapat al-Qârî bahwa 'Â'isyah mengatakan itu sebagai penolakannya terhadap orang-orang Jahiliah, yang menganggap tidak baik melangsungkan pernikahan pada bulanbulan haji (asyhur al-hajj) (al-Mubârakfûrî, t.th.: 215).

Agak berbeda dari al-Nawawî, al-Mubârakfûrî, dan al-Qârî, Shafâ' al-Dlawwî Ahmad al-'Adwî dalam mengomentari hadis koleksi Sunan Ibn Mâjah di atas menjelaskan bahwa kebiasaan 'Â'isyah tersebut hanya kebiasaan pribadinya sendiri karena Nabi menikahi dan berumahtangga dengannya pada bulan itu, tapi bukan berarti pernikahan pada bulan itu dianjurkan karena Nabi tidak selalu melakukannya dan tidak menikah selain bulan itu. Apalagi tidak ada riwayat yang menyatakan bahwa para sahabat Nabi memberi perhatian lebih pada pernikahan dalam bulan itu. Ia mengutip pendapat Ibn al-'Arabî dalam 'Âridlah alAhwadzî bahwa tidak ada ketentuan pasti tentang waktu pernikahan, baik berupa perintah maupun larangan. Hanya saja, al-'Adwî sependapat bahwa kepercayaan tentang kesialan bulan Syawal adalah kepercayaan batil (al-'Adwî, t.th.: 639640).

Patut disesali, kita tidak mendapatkan keterangan lain dari alSayyid Abû 'Âshim Nabîl ibn Hâsyim al-Ghamrî dalam Fath al-Mannân Syarh wa Tahqî̀ Kitâb al-Dârimî Abî Muhammad 'Abd Allâh ibn 'Abd al-Rahmmân saat mengomentari koleksi hadis dalam Musnad al-Dârimî atau Sunan al-Dârimî di atas. Ia hanya menukil pendapat alNawawî apa adanya, tanpa memberikan keterangan tambahan yang berarti. 
Untungnya, ia memberi informasi lebih lengkap tentang periwayatan hadis ini dalam kitab-kitab hadis, seperti dalam Mushannaf 'Abd al-Razzâq, Musnad Ahmad ibn Hanbal, Shahîh Muslim, Sunan alTirmidzî, Sunan al-Nasâ' $̂$, Sunan Ibn Mâjah, Thabaqât Ibn Sa'ad, al-Mu'jam al-Kabîr karya al-Thabrânî, al-Sunan al-Kubrâ karya al-Baihaqî, dan Syarh al-Sunnah karya alBaghawî (al-Ghamrî, 1999: 8/425-426).

Selain tidak adanya keterangan tambahan tersebut, kita juga tidak bisa mendapatkan keterangan tambahan berarti lain tentang dua koleksi hadis dalam Musnad Ahmad ibn Hanbal di atas. Dalam Bulûgh al-Amânî min Asrâr al-Fath al-Rabbânî, sebuah kitab syarh terhadap Musnad Ahmad ibn Hanbal, Ahmad 'Abd al-Rahnmân al-Bannâ al-Sâ'âtî (1301-1378 H.) hanya mengomentari satu hadis dari dua koleksi hadis tersebut. Menurutnya, berdasarkan hadis dalam Shahîh $\underline{h}$ alBukhârî, Shahîh Muslim, Musnad A hrmad, dan lainnya, Nabi menikahi 'Â'isyah pada saat 'Â'isyah berusia enam tahun, lalu berumahtangga dengannya pada saat usianya sembilan tahun. 'Â'isyah suka mempertemukan para kerabat perempuannya dengan para suaminya pada bulan Syawal karena meniru sunah Nabi (ittibâ'), bukan karena yakin bahwa hal itu akan mendatangkan kebahagiaan antara dua mempelai (al-Sâ'âtî, t.th.: 214).

\section{Tradisi Pernikahan pada Bulan Syawal Sebagai Living Hadith}

Data Rekap Nikah Rujuk (Model F1) Tahun 2013, 2014, 2015, dan 2016 Kabupaten Pamekasan H yang dikeluarkan oleh Kementerian Agama Kabupaten Pamekasan sebelumnya menunjukkan bahwa: pertama, pernikahan di Kecamatan Pamekasan Kabupaten Pamekasan lebih banyak digelar pada bulan Rabiulawal, Syawal, Zulkaidah, dan Zulhijah. Kedua, tradisi pernikahan di Madura yang biasanya digelar pada bulan Zulhijah, Jumadilawal, Syakban, dan Syawal sekarang mengalami pergeseran waktu; yang biasanya diselenggarakan pada bulan Jumadilawal dan Syakban kini berubah menjadi Rabiulawal dan Zulkaidah, sedangkan tradisi pernikahan di bulan Syawal dan Zulhijah tetap bertahan. Jika data itu ditambah dengan data pernikahan di Kantor Urusan Agama (KUA) Kecamatan Pamekasan untuk bulan Juli 2017 yang bertepatan dengan bulan Syawal 1438 H. sebanyak 107 pernikahan, bulan Agustus 2017 sebanyak 21 pernikahan, dan bulan September 2017 yang baru terdaftar hingga penelitian ini ditulis sekitar 40-an pernikahan (Kantor Urusan Agama (KUA) Kecamatan Pamekasan Kabupaten Pamekasan, 31 Agustus 2017 pukul 16.11 WIB).

Data tersebut menunjukkan bahwa selama empat tahun berurutan, yaitu dari tahun 2013 hingga tahun 2017, pernikahan pada bulan Syawal tetap bertahan pada kisaran 125 pernikahan (2013 M./1434 H.), 110 pernikahan (2014 M./1435 H.), 125 pernikahan (2015 M./1436 H.), 91 pernikahan (2016 M./1437 H.), dan 107 pernikahan (2017/1438 H). Data ini diperkuat dengan hasil wawancara dengan tiga belas informan yang sebagiannya sebagai berikut.

Ika Dwi Cahyadi, warga Desa Teja Timur Kecamatan Pamekasan, yang menikah dengan Zainuddin pada tanggal 07 Juli 2017 yang bertepatan dengan 13 Syawal 1438 H., mengatakan:

"Waktu-waktu yang dianggap baik
untuk pernikahan adalah sebelum
dan sesudah Idulfitri serta sebelum
dan sesudah Iduladha. Penentuan
tanggal itu merupakan petunjuk
dari kiai yang menganggapnya
sebagai waktu baik untuk
pernikahannya." (Wawancara pada
tanggal 28 September 2017) \begin{tabular}{l|l} 
Jurnal Multikultural \& Multireligius Vol. 17 & No. 1
\end{tabular} 
Namun Cahyadi tidak tahu bahwa Nabi Muhammad Saw. menikah dengan 'Â'isyah pada bulan Syawal, bulan yang sama dengan bulan pernikahannya. Pengakuan yang sama dilontarkan oleh Dimas Pangestu Gusti, warga Kelurahan Parteker Kecamatan Kota Pamekasan, yang menyatakan:

"Mereka tahu dari sesepuh kita, kiai, dan orang yang tahu arti bulan-bulan Islam. Mereka pantang menikah pada bulân Takèpè'. Mereka melaksanakan dan tidak melaksanakan pernikahan pada bulan-bulan tersebut agar pernikahan langgeng dan tidak ada perpisahan atau perceraian yang mengakibatkan keluarga itu hancur. Ada dalil yang menjelaskan itu, dan yang tahu itu hanya sesepuh kita dan kiai yang memberi bulan-bulan buat pernikahan, yang mungkin berupa ayat Alquran." (Wawancara pada tanggal 29 September 2017)

Abdul Wafi, seorang penghulu di Kantor Urusan Agama (KUA) Kecamatan Pamekasan, melihat ada perbedaan antara kebiasaan orang Madura asli dan orang Arab yang tinggal di Madura. Dia menuturkan:

“Orang Madura biasa menentukan waktu pernikahan pada waktu tertentu terutama pada bulan Syawal, Zulkaidah, dan Zulhijah. Berbeda dengan kebiasan orang Arab di Pamekasan yang biasa menggelar pernikahan kapan pun, tanpa terikat pada waktu tertentu, kebiasaan orang Madura ini merupakan tradisi Madura dalam menentukan waktu pernikahan (nyarè dhina), yang biasanya ditentukan setelah mereka sowan ke kiai, berdasarkan parèmbhun, atau berdasarkan tradisi yang sudah ada." (Wawancara pada tanggal 31 Agustus 2017)
Namun Wafi tidak mengetahui bahwa pernikahan pada bulan Syawal yang sudah menjadi tradisi orang Madura tersebut sebenarnya merupakan sunah Nabi Muhammad Saw. karena beliau menikahi 'Â'isyah dan Ummu Salamah pada bulan ini. Penentuan waktu pernikahan dipertegas oleh Moh. Mashur Abadi, akademisi dan pemerhati budaya Madura, sebagai berikut:

"Ragam pernikahan di Madura merupakan hasil akulturasi budaya dan agama, sehingga ia tidak menemukan satu pun prosesi pernikahan yang genuine Madura, baik dari segi prosesi, asesoris, maupun waktu pernikahan, seperti penggunaan petasan dalam prosesi pernikahan yang merupakan pengaruh dari budaya Cina dan asesoris serta penentuan waktu pernikahan yang merupakan pengaruh dari budaya Jawa dan Islam, yang menggunakan primbon (parèmbhun) atau menggunakan bulan-bulan tertentu. Ada perbedaan mendasar antara pengaruh budaya Jawa dan Islam dalam menentukan waktu pernikahan; dalam Islam pernikahan ditentukan berdasarkan bulan, sedangkan dalam budaya Jawa pernikahan ditentukan berdasarkan hari yang dalam tradisi Madura disebut sebagai nyarè dhina." (Wawancara pada tanggal 09 September 2017)

Secara lebih teknis, Moh. Zahid, seorang Wakil Ketua Tanfidziyah PCNU Pamekasan dan Ketua Lembaga Pengkajian dan Penerapan Syariat Islam (LP2SI) Pamekasan, mengungkap metode penentuan waktu pernikahan di Madura sebagai berikut:

“Mereka menggelar pernikahan pada hari dan bulan tertentu atas dasar keyakinan bahwa waktu itu 
merupakan waktu yang baik untuk pernikahan. Dalam menentukan waktu pernikahan, mereka biasanya bertanya kepada orang pintar, yang di Madura biasanya adalah kiai. Kiai inilah yang memberikan legitimasi terhadap keyakinan mereka tersebut." (Wawancara pada tanggal 26 September 2016)

Pernyataan menarik dilontarkan oleh Ibnu Kusuma Negara, anggota Komisi Fatwa MUI Pamekasan dan ketua Majlis Tarjih Muhammadiyah Pamekasan. Sebagai warga Muhammadiyah, dia melihat fenomena yang sama dalam tradisi pernikahan di Madura, terutama di Pamekasan. Dia menuturkan:

"Mereka biasa menentukan waktu pernikahan pada hari dan bulan tertentu dengan kitab mujarrabat. Bulan yang bagus bagi mereka adalah adalah Syawal, Zulhijah, dan Muharam, sedangkan bulan yang tidak bagus adalah Syakban dan Safar." (Wawancara pada tanggal 28 September 2017)

Dalam pandangannya, tidak ada dalil apa pun dalam menentukan hari baik dan tidak baik, karena semua hari baik dan hanya tradisi yang sudah turun-temurun. Senada dengan Negara yang menganggap penentuan waktu pernikahan berdasarkan kitab mujarrabat, Ahmad Zayyadus Zabidi, Kasi Bimas Islam Kemenag Pamekasan, mengatakan:

"Mereka biasa menggelar
pernikahan pada waktu-waktu
tertentu. Penentuan hari dan
bulan itu ditempuh dengan cara
perhitungan tertentu. Mereka juga
mengenal hari dan bulan pantangan
untuk menikah. Hal ini bersumber
dari kitab-kitab mujarrabat dan
semacamnya." (Wawancara pada
tanggal 29 September 2017)

“Mereka biasa menggelar pernikahan pada waktu-waktu tertentu. Penentuan hari dan bulan itu ditempuh dengan cara perhitungan tertentu. Mereka juga mengenal hari dan bulan pantangan untuk menikah. Hal ini bersumber dari kitab-kitab mujarrabat dan tanggal 29 September 2017)
Teknis penentuan waktu pernikahan secara lebih rinci diungkap oleh Akh. Syaiful Rijal, Dewan Pengasuh Pondok Pesantren Babus Salam Kelurahan Kanginan Kecamatan Kota Pamekasan, sebagai berikut:

"Ada rumus hitung-hitungan untuk menentukan tanggal pernikahan, yang biasanya dilakukan dengan menentukan bilanganbilang tertentu, seperti tanggal satu "bismillah", tanggal dua "alhamdulillah", dan tanggal tiga "innalillah" untuk kalender Hijriah. Penghitungan ini dihitung secara terus-menerus hingga tanggal 30." (Wawancara pada tanggal 25 September 2017)

Berdasarkan wawancara dengan tiga belas informan yang sebagiannya sudah disebut di atas, terungkap bahwa orang Madura biasa menyelenggarakan pernikahan pada bulan-bulan tertentu, termasuk bulan Syawal sebagaimana praktik pernikahan Nabi dengan 'Â'isyah dan Ummu Salamah. Menarik untuk dicatat, semua informan tersebut tidak mengetahui dan tidak bisa menyebutkan dalil bahwa Nabi Muhammad Saw. menikah dengan 'Â'isyah dan Ummu Salamah pada bulan Syawal yang melabrak tradisi Jahiliah karena dianggap sebagai bulan sial untuk pernikahan. Padahal sebagian informan merupakan tokoh penting di lingkungan MUI, NU, Muhammadiyah, Kemenag, dan kampus. Bahkan seorang informan yang merupakan satu-satunya penghulu di Kecamatan Pamekasan pun demikian.

Berdasasarkan data tersebut, tidak berlebihan bila dikatakan bahwa penentuan bulan pernikahan yang merupakan pengaruh Islam sudah mengakar kuat di tengah masyarakat Kecamatan Pamekasan Kabupaten Pamekasan, sehingga sebagian besar 
mereka tidak menyadarinya dengan dua alasan: pertama, penentuan bulan baik untuk pernikahan lebih dianggap sebagai tradisi belaka, sehingga mereka tidak dapat menyadari bahwa itu merupakan pengaruh dari Islam. Bila dibanding pengaruh Islam yang lain seperti khotbah nikah, wali, akad, dan mahar, maka penentuan bulan baik untuk pernikahan lebih susah dideteksi sebagai pengaruh dari Islam, dan kedua, sebagian besar masyarakat Kecamatan Pamekasan tidak mengetahui bahwa pernikahan pada bulan Syawal merupakan sunah Nabi, yang kuat dugaan telah dipraktikkan oleh umat Islam di Madura generasi awal dan kemudian diwariskan secara turuntemurun.

Mereka mengetahui atau tidak tentang dalil pernikahan pada bulan Syawal, yang jelas pernikahan pada bulan Syawal di Kecamatan Pamekasan merupakan tradisi yang terus bertahan hingga sekarang. Berdasarkan wawancara dengan tiga belas informan di atas, terungkap bahwa bulan Syawal termasuk bulan yang dianggap baik oleh orang Madura untuk melangsungkan pernikahan. Hal ini sesuai dengan Rekap Nikah Rujuk (Model F1) Tahun 2013, 2014, 2015, dan 2016 Kabupaten Pamekasan yang dikeluarkan oleh Kementerian Agama Kabupaten Pamekasan sebagaimana telah diungkap pada pembahasan sebelumnya.

Berdasarkan seluruh paparan di atas, ada dua alasan utama tradisi pernikahan pada bulan Syawal di Kecamatan Pamekasan Kabupaten Pamekasan dikategorikan sebagai living hadith: (a) Mayoritas penduduk Madura, termasuk penduduk Kecamatan Pamekasan Kabupaten Pamekasan, beragama Islam; dan (b) Dalam menentukan menentukan pernikahan, mereka biasa berkonsultasi kepada kiai atau sesepuh dan menggunakan primbon serta kitab mujarrabat. Kiai adalah figur yang menekuni tradisi keilmuan Islam, sehingga dalam menentukan waktu pernikahan mereka biasa menggunakan dalil atau berpatokan pada primbon dan kitab mujarrabat. Sesepuh adalah sosok yang dianggap lebih mengetahui tradisi setempat, dan ia pun tahu dari sesepuh pada generasi sebelumnya yang bisa saja juga mengetahui dari kiai. Primbon hanya menentukan hari pernikahan, tapi bukan bulan pernikahan, sehingga penentuan bulan Syawal untuk pernikahan bukan wilayah primbon. Sedangkan kitab mujarrabat adalah kitab yang memadukan tradisi Arab, Persia, Islam, dan lainnya sehingga pengaruh Islam terhadap kitab mujarrabat yang dijadikan acuan penentuan bulan pernikahan tidak dapat dipungkiri.

\section{SIMPULAN}

Islam memandang pernikahan sebagai fenomena sosial penting yang mengandung unsur ibadah. Bahkan pernikahan menentukan kesempurnaan keislaman seorang. Dalam Islam, pernikahan termasuk perkara penting sehingga termasuk dalam satu kategori dalam al-dlarûrîyât al-khamsah, yaitu untuk menjaga keturunan (hifdz al-nasl), yang menurut al-Syâthibî harus dilakukan agar mendapatkan kemaslahatan hidup di dunia dan akhirat. Kemasalahatan ini bisa dicapai dengan pernikahan, sehingga Allah Swt. memasukkannya dalam syariat-Nya, baik melalui Alquran maupun melalui Nabi Muhammad Saw. Tradisi pernikahan di Madura bermacam-macam baik jenis, bentuk, dan tata caranya. Dalam tradisi intelektual Islam, ada kaidah usul fikih "al-'âdah muhakkamah" (adat itu dihukumkan atau adat adalah syariat yang dihukumkan). Islam memandang tradisi pernikahan di Madura sebagai sebuah kearifan lokal yang secara substantif tidak bertentangan dengan Islam. Dengan kata lain, varian

\begin{tabular}{l|l} 
HARMONI & Januari - Juni 2018
\end{tabular} 
tradisi pernikahan di Madura meski berbeda dari segi jenis, bentuk, dan tata caranya, tapi secara umum sesuai dengan Islam. Tradisi pernikahan di bulan Syawal di Kecamatan Pamekasan Kabupaten Pamekasan Madura merupakan perpaduan antara tradisi Madura dan Islam. Ia adalah living hadith, yaitu praktik pernikahan yang eksistensinya terilhami oleh hadis atau sunah Nabi yaitu hadishadis yang diriwayatkan oleh Muslim, alTirmidzî, al-Nasâ'î, Ibn Mâjah, al-Dârimî, dan Ahmad.

\section{UCAPAN TERIMA KASIH}

Artikel ini tidak akan terwujud tanpa bantuan dan dukungan dari beberapa pihak. Oleh karena itu, penulis berterimakasih kepada Rektor Institut Agama Islam Negeri (IAIN) Madura, Kepala Lembaga Penelitian dan Pengabdian kepada Masyarakat (LPPM) Institut Agama Islam Negeri (IAIN) Madura, Komunitas Dosen M18D Institut Agama Islam Negeri Madura, pegawai Kementerian Agama Kabupaten Pamekasan, pegawai Kantor Urusan Agama (KUA) Kecamatan Pamekasan Kabupaten Pamekasan, Majelis Ulama Indonesia (MUI) Pamekasan, Lembaga Pengkajian dan Penerapan Syariat Islam (LP2SI) Pamekasan, dan para informan. Terakhir, secara khusus, penulis juga berterima kasih kepada para pengelola dan mitra bestari Jurnal Harmoni yang telah memberikan catatan dan saran untuk perbaikan artikel ini, sehingga bisa diterbitkan pada Jurnal Harmoni edisi kali ini.

\section{DAFTAR ACUAN}

Aplikasi KBBI Offline 1.5.1

'Adwî, Shafâ' al-Dlawwî Ahmad (al-). Ihdâa' al-Dîbâjah bi Syarh Sunan Ibn Mâjah. Juz 2. t.k.: Dâr al-Yaqîn, t.th.

Aini, Adrika Fithrotul. "Living Hadis dalam Tradisi Malam Kamis Majelis Shalawat Diba' Bil-Mustofa". Ar-Raniry: International Journal of Islamic Studies. Vol. 2, No. 1 (Juni, 2014): 227.

'Alî, Jawwâd. Al-Mufashshal fî Târîkh al-'Arab qabla al-Islâm. Juz 5. t.k.: t.p., 1993.

Bâqî, Muhammad Fu'âd 'Abd (al-). Al-Mu'jam al-Mufahras li Alfâdz al-Qur'ân al-Karîm. Kairo: Dâr al-Kutub al-Mishrîyah, 1364 H.

Bukhârî, Abû ‘Abd Allâh Muhammad ibn 'Ismâ'îl (al-). Shahîh al-Bukhârî. Damaskus: Dâr Ibn Katsîr, 2002.

Dârimî, Abû Muhamamad 'Abd Allâh ibn 'Abd al-Rahmân ibn al-Fadl ibn Bahrâm (al-). Sunan al-Dârimî. Riyad: Dâ al-Mughnî, 2000.

Ghamrî, Al-Sayyid Abû 'Âshim Nabîl ibn Hâsyim (al-). Fath al-Mannân Syarh wa Tahq Kitâb al-Dârimî Abî Muhammad 'Abd Allâh ibn 'Abd al-Rahmân. Juz 8. Beirut: Dâr al-Basyâ'ir al-Islâmîyah, 1999.

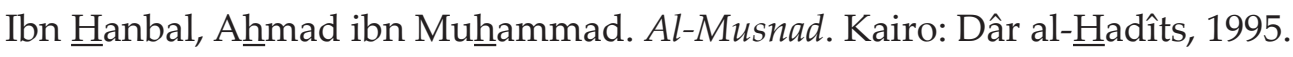

Ibn Mandzûr. Lisân al-'Arab. Juz 4. Kairo: Dâr al-Ma'ârif, t.th.

Jurjânî, 'Alî ibn Muhammad al-Sayyid al-Syarîf (al-). Mu'jam al-Ta'rîfât. Kairo: Dâr alFadlîlah, t.th.

Kementerian Agama Kabupaten Pamekasan. Rekap Nikah Rujuk (Model F1) Tahun 2013, 2014, 2015, dan 2016 Kabupaten Pamekasan. 
Mubârakfûrî, Abû al-'Alî Muhammad ibn 'Abd al-Rahmân ibn 'Abd al-Rahîm (al-). Tuhfah al-Ah̆wadzî bi Syarh Jâmi' al-Tirmidzî. Juz 4. t.k.: Dâr al-Fikr, t.th.

Nasâ'î, Abû 'Abd al-Rahmmân Ahmad ibn Syu'ayb ibn 'Alî (al-). Sunan al-Nasấî. Riyad: Al-Ma'ârif, t.th.

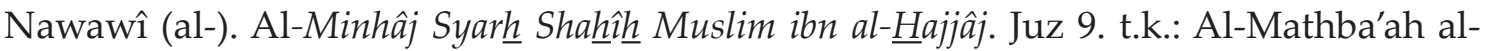
Mishrîyah bi al-Azhar, 1929.

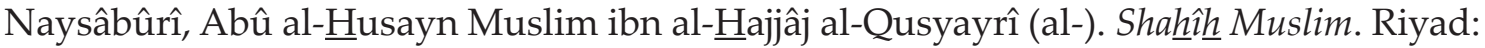
Dâr al-Mughnî, 1998.

Nurdiana, Venita. "Pangantan Tandu Tradisi Pernikahan Masyarakat Desa Legung Kabupaten Sumenep." Jurnal Online Universitas Negeri Malang: 1-26. http://jurnalonline.um.ac.id/data/artikel/artikel8D0141573942034D78F7598790CBDFA4.pdf (Diakses pada tanggal 20 Maret 2017 pukul 12.35 WIB)

Qazwaynî, Abû 'Abd Allâh Muhammad ibn Yazîd (al-). Sunan Ibn Mâjah. Riyad: AlMa'ârif, t.th.

Qudsy, Saifuddin Zuhry. "Living Hadis: Genealogi, Teori, dan Aplikasi". Jurnal Living Hadis. Vol. 1, No. 1 (Mei, 2016): 189-194.

Rochmah, Siti. Perkawinan Salēp Tarjhâ pada Masyarakat Kecamatan Pengarengan Kabupaten Sampang Madura Ditinjau dari Hukum Islam. Skripsi, Universitas Islam Negeri Syarif Hidayatullah Jakarta, 2011.

Sâ'âtî, Ahmad 'Abd al-Rahmân al-Bannâ (al-). Bulûgh al-Amânî min Asrâr al-Fath alRabbânî. Juz 16. Beirut: Dâr Ihyâ' al-Turâts al-'Arabî, t.th.

Sijistânî, Abû Dâwud Sulaymân ibn al-'Asy'ats (al-). Sunan Abî Dâwwud. Riyad: Al-Ma'arif, t.th.

Suryadilaga, Muhammad Alfatih. "Living Hadis dalam Tradisi Sekar Makam". AlRisalah. Vol. 13, No. 2 (Mei, 2013): 165.

Syâthibî, Abû Ishâq (al-). Al-Muwâfaqât fî̀ Ushûl al-Syarî'ah. Juz 2. KSA: Wazârah alSyu'ûn al-Islâmîyah wa al-Awqâf wa al-Da'wah wa al-Irsyâd, t.th.

Tirmidzî, Muhammad ibn 'Îsâ ibn Sawrah (al-). Sunan al-Tirmidzî. Riyad: Al-Ma'ârif, t.th.

\section{Wawancara:}

Abdul Wafie, Wawancara, pada tanggal 31 Agustus 2017.

Moh. Mashur Abadi, Wawancara, pada tanggal 09 September 2017.

Akh. Syaiful Rijal, Wawancara, pada tanggal 25 September 2017.

Moh. Zahid, Wawancara, pada tanggal 26 September 2016.

Ibnu Kusuma Negara, Wawancara, pada tanggal 28 September 2017.

Ika Dwi Cahyadi, Wawancara, pada tanggal 28 September 2017.

Ahmad Zayyadus Zabidi, Wawancara, pada tanggal 29 September 2017.

Dimas Pangestu Gusti, , Wawancara, pada tanggal 29 September 2017. 